\title{
Effect of removal of free-floating macrophytes on zooplankton habitat in shallow wetland
}

\author{
Jong-Yun Choi ${ }^{(1)}$, Kwang-Seuk Jeong ${ }^{(1),(2)}$, Geung-Hwan La ${ }^{(3)}$, \\ Gea-Jae Joo(1),
}

Received February 18, 2014

Revised June 23, 2014

Accepted June 24, 2014

Key-words: submerged macrophyte, macrophyte habitat, zooplankton, species diversity, shallow wetland

\section{ABSTRACT}

Submerged macrophytes improve the structural heterogeneity of microhabitats in aquatic ecosystems, often providing an important habitat for zooplankton. However, excessive development of free-floating macrophytes on the water surface can reduce the biomass of submerged macrophytes and result in a relatively simple habitat structure. We hypothesized that controlling the development of free-floating macrophytes would result in a more complex habitat structure by promoting the development of submerged macrophytes. After applying three experimental treatments (NR, no removal; IR, intermediate removal; CR, complete removal of free-floating macrophytes), we found that CR of free-floating macrophytes improved the growth and development of submerged macrophytes and supported a large zooplankton assemblage. However, the largest zooplankton assemblage (in terms of abundance and diversity) was recorded after the IR treatment. Although submerged macrophytes were abundant in the $\mathrm{CR}$ treatment, the number, abundance, and density of zooplankton species were much lower than those in the IR treatment. Preferential selection of different macrophyte types by zooplankton presumably led to variation in plant utilization of niches, and the simultaneous presence of different macrophyte life forms created a complex microhabitat structure that induced high species diversity and zooplankton density.

RÉSUMÉ

Effet du retrait des macrophytes flottants sur l'habitat du zooplancton dans les zones humides peu profondes

Mots-clés : macrophytes submergés, habitat des macrophytes,
Les macrophytes submergés améliorent l'hétérogénéité structurelle des microhabitats dans les écosystèmes aquatiques, offrant souvent un habitat important pour le zooplancton. Cependant, le développement excessif des macrophytes flottants à la surface de l'eau peut réduire la biomasse des macrophytes submergés et aboutir à une structure de l'habitat relativement simple. Nous avons supposé que le contrôle du développement des macrophytes flottants se traduirait par une structure de l'habitat plus complexe en favorisant le développement des

(1) Department of Biological Sciences, Pusan National University, Busan 609-735, Republic of Korea

(2) Institute of Environmental Science \& Technology, Pusan National University, Busan 609-735, Republic of Korea

(3) Department of Environmental Education, Sunchon National University, Suncheon, Jeonnam 540-742, Republic of Korea

^ Corresponding author: Jyc311@naver.com 
zooplancton, diversité des espèces, zones humides peu profondes macrophytes submergés. Après l'application de trois traitements expérimentaux (pas de suppression, suppression intermédiaire, et la suppression complète des macrophytes flottants), nous avons constaté que l'élimination complète des macrophytes flottants améliore la croissance et le développement des macrophytes submergés et favorise un important assemblage de zooplancton. Cependant, la plus grande communauté de zooplancton (en termes d'abondance et de diversité) a été constatée après le traitement de suppression intermédiaire. Bien que les macrophytes submergés soient abondants dans le traitement de suppression complète, le nombre, l'abondance et la densité des espèces de zooplancton ont été beaucoup plus faibles que dans le traitement de suppression intermédiaire. Une sélection préférentielle des différents types de macrophytes par le zooplancton conduit probablement à la variation de l'utilisation des niches végétales, et la présence simultanée de différentes formes de vie de macrophytes a créé une structure de micro-habitat complexe qui induit une grande diversité d'espèces et la densité du zooplancton.

\section{INTRODUCTION}

Aquatic macrophytes are the determining factor in the overall structure of freshwater ecosystems. Macrophytes can have dramatic effects on the physical structure of aquatic habitats (O'Hare et al., 2006; Smokorowski and Pratt, 2007) and create a heterogeneous mosaic at different scales. Some studies have suggested that structural heterogeneity of macrophytes mediates trophic interactions among various biota (Jeppesen et al., 1997; Pelicice and Agostinho, 2006) and significantly influences the biodiversity of the zooplankton community (Tolonen et al., 2005). Among animals that use aquatic macrophytes in freshwater ecosystems, zooplankton are located at an intermediate level of the food web and play a key role in transferring energy and materials within the food web (Wetzel and Likens, 2000). Thus, the relationship between habitat characteristics (i.e., macrophytes) and zooplankton has gradually become central to limnological research.

Among the various macrophyte life forms, submerged macrophytes generally increase the physical complexity of aquatic environments and provide a suitable habitat for colonization by zooplankton. However, free-floating macrophytes also play a fundamental structural role (Meerhoff et al., 2003). Consequently, we expect that the development of diverse types of macrophytes (submerged and free-floating) will create more physically complex habitats in aquatic ecosystems and support high zooplankton biodiversity. In contrast, extensive cover by free-floating macrophytes is expected to reduce underwater biomass as a result of shading effects (Gross et al., 2007). In other words, excessive growth of free-floating macrophytes would be expected to induce a relatively simple habitat structure, leading to a smaller, less diverse assemblage of zooplankton. To date, this dynamic has not been extensively studied. The main objective of our study was to examine the influence of free-floating macrophyte development on the diversity of the zooplankton community in shallow wetlands. We used a quadrat-based experiment to investigate the response of the zooplankton community to artificial control of the amount of free-floating macrophytes. We expected that controlling the development of free-floating macrophytes would promote a more complex habitat structure and encourage the development of submerged macrophytes. Therefore, we investigated the effects of control of free-floating macrophytes on the development of submerged macrophyte biomass and the contribution of these control measures to zooplankton biodiversity and density.

\section{MATERIALS AND METHODS}

South Korea is located in East Asia and has a temperate climate Four distinct seasons lead to dynamic succession among biological communities in freshwater ecosystems. In this study, 


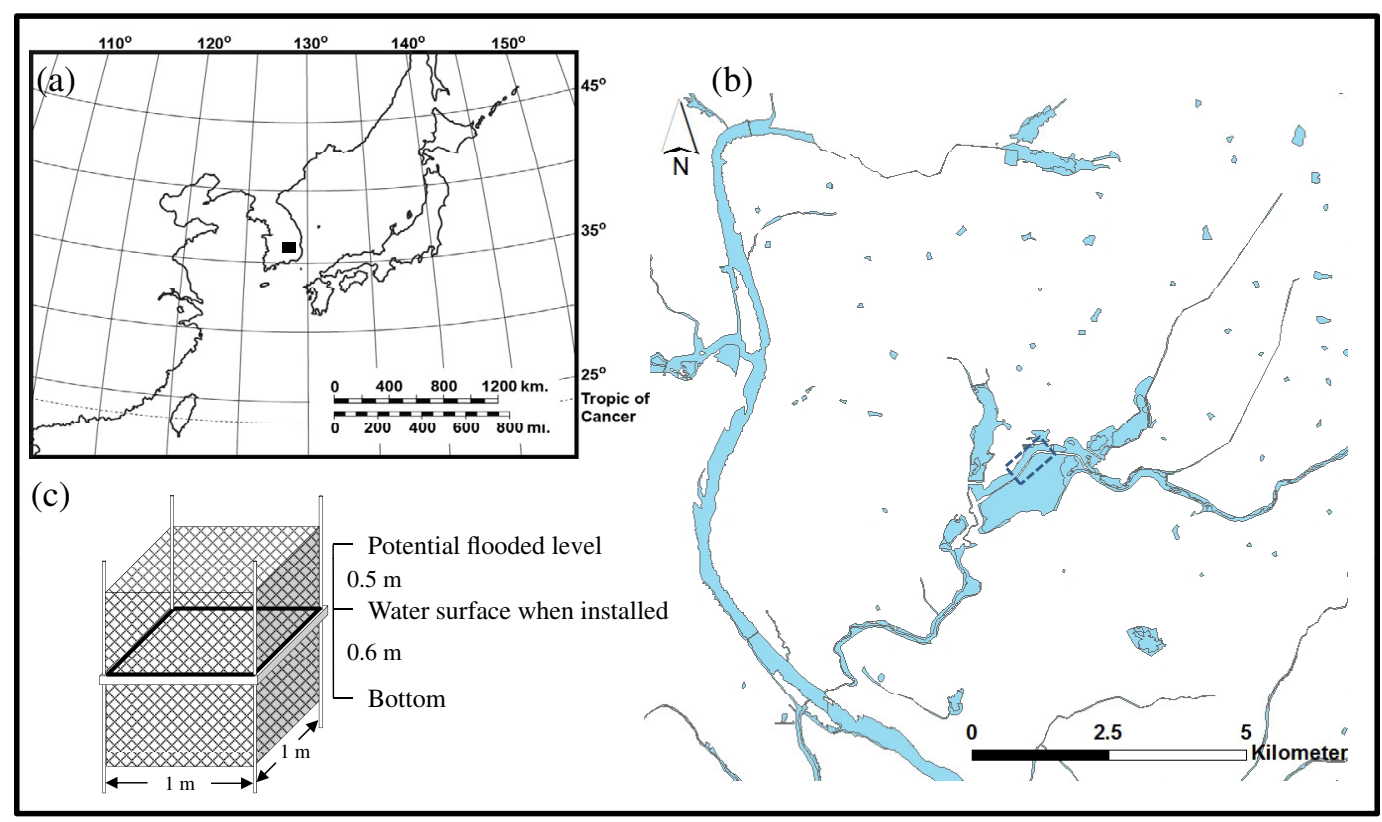

Figure 1

Map of the study sites. The sites located in southeastern South Korea are indicated by solid squares (ロ). (a) The Korean Peninsula (b) the Upo Wetland, and (c) the shape of the quadrats installed at the study site.

we focused on the Upo Wetland in southeastern Korea (Figure 1) in the mid- to lower reaches of the Nakdong River. The wetland's surface water area is $2.7 \mathrm{~km}^{2}$ and the average depth ranges from 0.8 to $1.4 \mathrm{~m}$. The Upo Wetland is almost completely covered by macrophytes from spring (May) to autumn (November) We observed two species of free-floating macrophytes (Salvinia natans and Spirodela polyrhiza) and three species of submerged macrophytes (Najas graminea, Ceratophyllum demersum, and Hydrilla verticillata) at the study site.

We implemented biannual monitoring (2011 and 2012) at the Upo Wetland between May and November. Before the initiation of monitoring, we explored candidate locations with similar macrophyte species composition and established nine quadrats $\left(1 \mathrm{~m}^{2}\right)$ in the Upo Wetland (Figure 1C). First, we installed 36 poles at the sampling points $(0.05 \mathrm{~m}$ in diameter, $2 \mathrm{~m}$ in length; 4 poles per quadrat). Poles were sunk into the sediment to a depth of more than $15 \mathrm{~cm}$ in order to prevent them from falling down. Every four poles were encircled with a porous screen $\left(1 \mathrm{~cm}^{2}\right.$ mesh). The mesh screen extended to the bottom (approximately $0.6 \mathrm{~m}$ from the water surface) and emerged above the water surface (approximately $0.5 \mathrm{~m}$ ). The screens were tightly affixed to the poles and placed on the water surface. The mesh screens were positioned to prevent the intrusion of free-floating macrophytes from outside. Nine quadrats were sequentially located along the littoral area, separated by $0.5 \mathrm{~m}$.

The quadrats were grouped into three treatments as follows: (i) no removal of free-floating macrophytes (No Removal, NR); (ii) removal of $50 \%$ of the free-floating macrophytes (Intermediate Removal, IR); and (iii) complete removal of free-floating macrophytes (Complete Removal, CR). We removed free-floating macrophytes from the surface of the quadrats in the $\mathrm{IR}$ and CR treatment groups at biweekly intervals. To determine the quantity of free-floating macrophytes in the IR quadrats, we measured their coverage and then removed half of the plants, leaving the remaining free-floating plants to cover half the area of the quadrats.

We investigated environmental variables, zooplankton and submerged macrophytes in each quadrat at biweekly intervals. A dissolved oxygen (DO) meter (YSI Model 58, USA) was used to measure water temperature and dissolved oxygen; conductivity and $\mathrm{pH}$ were measured using a conductivity meter (YSI model 152; Yellow Springs Instruments, Yellow Springs, $\mathrm{OH}$, USA) and a pH meter (Orion Model 250A; Orion Research Inc., Boston, MA, USA), respectively. The water samples were taken to the laboratory to measure turbidity and concentration 
of chlorophyll a. Turbidity was measured using a turbidimeter (Model 100B; Scientific Inc., Ft. Myers, FL, USA). The water samples were filtered through a mixed cellulose ester membrane filter (Advantech; Model No., A045A047A; pore size, $0.45 \mu \mathrm{m}$ ); the filtrate was used to determine the concentration of chlorophyll a, according to the method described by Wetzel and Likens (2000). For zooplankton collection, we collected water samples using a $10 \mathrm{~L}$ column sampler $(6.3 \mathrm{~cm}$ radius, $80 \mathrm{~cm}$ in height). The sampler was placed vertically in the water to collect zooplankton from the entire water column of a quadrat, including submerged and/or free-floating macrophytes.

We stored the sampled water (including any macrophytes collected) in a tank. The collected macrophytes were shaken in the tank to detach zooplankton (Sakuma et al. 2002), and macrophytes were then removed from the tank. The volume of the remaining water sample (containing zooplankton from both the water column and macrophytes) was measured to calculate zooplankton density and was filtered through a plankton net $(32-\mu \mathrm{m}$ mesh) The filtrate was preserved in formaldehyde (final concentration approximately $5 \%$ ). Zooplankton were identified and counted using a microscope (Zeiss, Model Axioskop 40; $200 \times$ magnification), according to the classification of Mizuno and Takahashi (1999).

After zooplankton collection, we collected submerged macrophytes from each quadrat. We established a virtual grid $\left(20 \mathrm{~cm}^{2}\right)$ over the quadrats and completely sampled the submerged macrophytes within each cell of the grid at each sampling time. Sampling was based on a random number to avoid bias. Submerged macrophyte samples were collected using a core sampler $(20 \times 20 \times 30 \mathrm{~cm})$ and sediment was excluded from the sample by shaking the sample in clear water. The collected macrophytes were then dried in the laboratory at $60^{\circ} \mathrm{C}$ for 2 days and macrophyte dry weight was estimated for each quadrat.

Species diversity of zooplankton $\left(H^{\prime}\right)$ was calculated according to the following equation (Shannon and Weaver, 1963):

$$
H^{\prime}=-\sum P i \log _{2} P i(P i=N i / N)
$$

where $\mathrm{Ni}$ is the number of individual organisms of the species, and $N$ is the total number of individuals.

We used one-way analysis of variance (ANOVA) to compare differences among the treatment groups in aquatic environmental variables, submerged macrophyte dry weight and zooplankton density using SPSS for Windows (version 14).

\section{RESULTS}

Figure 2 shows changes in environmental variables in relation to macrophyte removal treatment. Water temperature and conductivity showed the strongest seasonality but were not influenced by plant removal. In contrast, the percentage saturation of dissolved oxygen and $\mathrm{pH}$ were clearly affected by the removal of free-floating macrophytes (one-way ANOVA, $d f=2$, $F=36.4, p<0.01$ ). The highest values for percentage saturation of dissolved oxygen and $\mathrm{pH}$ were observed in the CR quadrats, followed by IR quadrats. The highest values of turbidity and chlorophyll a were also observed in the CR quadrats. Moreover, the concentration of chlorophyll a was noticeably enhanced after the two removal treatments (IR and CR).

The quantity of submerged macrophytes varied inversely with the coverage of free-floating macrophytes (Figure 3). Both free-floating and submerged macrophytes began to grow in May; however, the dry weight of submerged macrophytes decreased in July when the cover of free-floating macrophytes exceeded $50 \%$, resulting in very low dry weight between August and September. The dry weight of submerged macrophytes was restored in October and November as the percentage cover of free-floating macrophytes decreased. Although the second year of observations revealed that there was inter-annual variability in the magnitude of dry weight, the patterns of seasonal change were almost identical (Figure 3a). On the basis of this result, we assumed that the dry weight of submerged macrophytes was dependent on the coverage of free-floating macrophytes. 

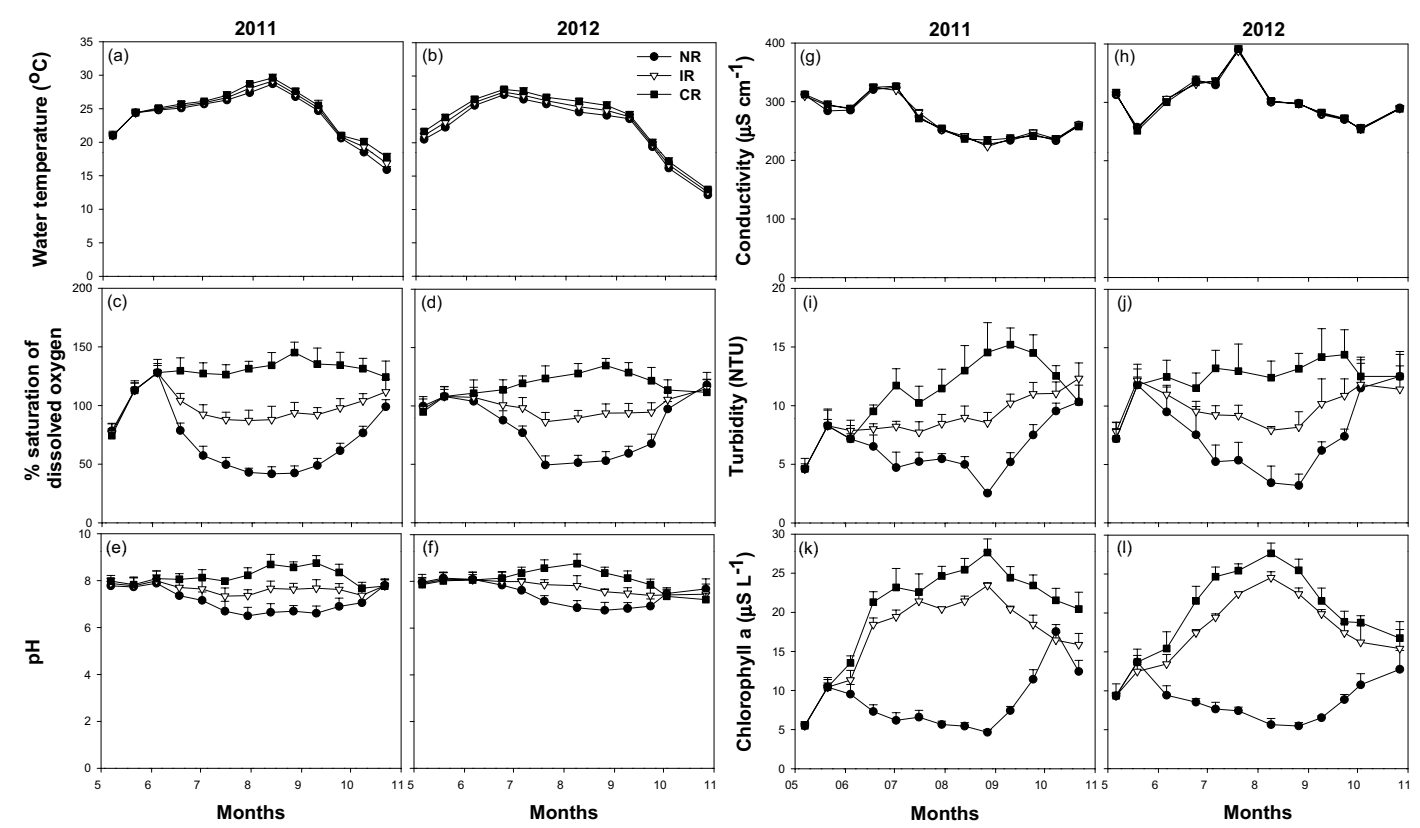

Figure 2

Seasonal variation in environmental variables according to the level of free-floating macrophyte removal at the study site. NR, No Removal; IR, Intermediate Removal; CR, Complete Removal.

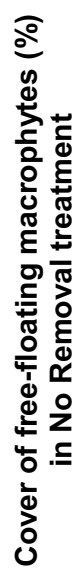

2011

$$
\text { (a) }
$$

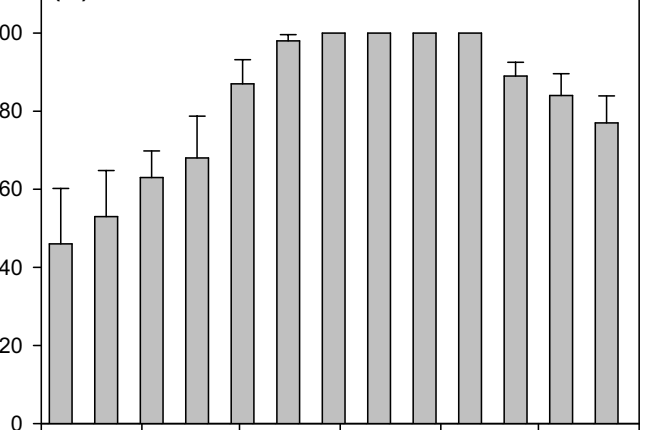

$$
\text { (c) }- \text { NR }
$$

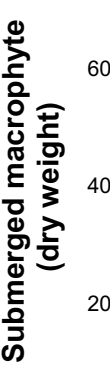

(b)

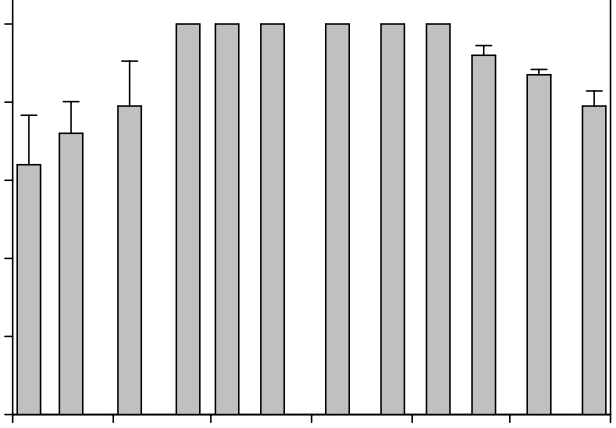

(d)

b)

2012

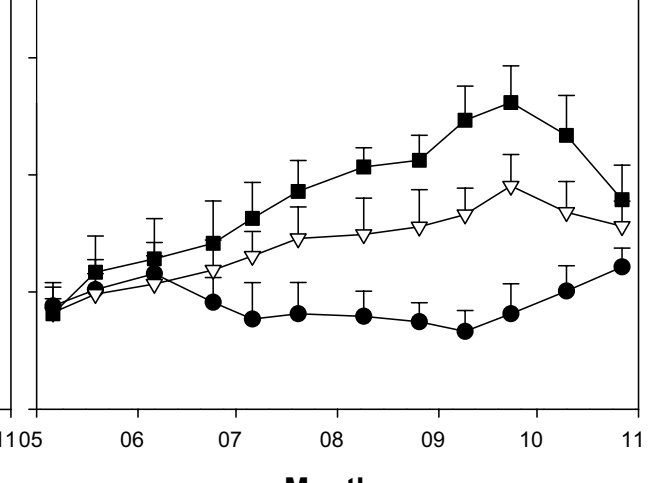

Months

Figure 3

Coverage of free-floating macrophytes (\%) and dry weight (grams) of submerged macrophytes at the study site. Submerged macrophytes showed seasonal changes in dry weight in association with the level of free-floating macrophyte removal NR, No Removal; IR, Intermediate Removal; CR, Complete Removal. 
Our experimental removal of free-floating macrophytes improved the growth of submerged plants, as shown by an increase in their measured dry weights (one-way ANOVA, $d f=2$, $F=31.1, p<0.01$; Figures $3 b$ and $3 c$ ). In the NR quadrats, a pattern of seasonal change was evident, and the dry weight of submerged macrophytes was reduced in August and September. However, in the IR quadrats, a gradual increase in the dry weight was observed in both study years (Figure $3 b$ ). In the CR quadrats, the summer pattern of decrease also disappeared, and the dry weight of submerged macrophytes increased almost two-fold compared with that found in the IR quadrats (Figure 3c).

A total of 49 zooplankton species were found in the Upo Wetland; 29 species belonged to Aschelminthes and the remaining 20 species to Arthropoda (Table I). Removal of free-floating macrophytes was strongly associated with a greater number of zooplankton species. The fewest zooplankton species (11 species) were found after NR treatment, whereas 19 species were found after CR treatment and 40 species were found after IR treatment. The removal treatments also led to a shift in species composition. Small zooplankton (mainly rotifers and small cladocerans) were found after NR treatment, whereas larger zooplankton, which are more planktonic, were found after CR treatment. Most zooplankton species found after IR treatment were also observed after the other treatments, but some additional species were also observed.

Zooplankton density also clearly varied with removal treatment (Figure 4). The lowest density of zooplankton was maintained after NR treatment. Although more than $100 \mathrm{ind} \cdot \mathrm{L}^{-1}$ were found in this treatment group between May and June, the number gradually decreased, beginning in August. We observed the same pattern in zooplankton species diversity. In contrast, removal of free-floating macrophytes supported a greater zooplankton assemblage. The highest abundance and diversity of zooplankton were found in the IR quadrats, followed by the $\mathrm{CR}$ quadrats. Zooplankton density was significantly different among the treatments (one-way ANOVA, $d f=2, F=60.6, p<0.01)$.

\section{DISCUSSION}

In this study, the removal of free-floating macrophytes led to clear differences in submerged macrophyte biomass. Although both submerged and free-floating macrophytes were present at the beginning of the experiment, the biomass of the former decreased as the colony of floating macrophytes developed and covered the water surface. The dominance of freefloating macrophytes reduced light penetration, inhibiting the growth of the submerged plants. Light and water temperature are closely related to the growth of submerged macrophytes; these factors determine the structure, shape, and biomass of individual plants and colonies (Barko et al., 1982). Forchhammer (1999) also found that the production of the submerged macrophyte Elodea was reduced when dense growth of free-floating Azolla fully covered the water surface.

Repeated removal of free-floating macrophytes may improve the growth and development of submerged macrophytes relative to areas that are completely covered. Removal treatment may enhance the opportunity for the submerged macrophytes to utilize light. We found that the biomass of submerged macrophytes was almost proportional to the intensity of freefloating macrophyte removal. Submerged macrophytes with greater biomass form more heterogeneous microhabitat structures than other plant life forms (Manatunge et al., 2000). Although submerged macrophytes have strong allelopathic effects, they enhance edible prey resources for zooplankton (van Donk and van de Bund, 2002) Therefore, higher the light penetration in the wetland water column, larger the potential zooplankton community structure induced by colonial-type macrophytes.

Strikingly, the largest zooplankton abundance and diversity were recorded after IR treatment. Even though submerged macrophytes were abundant after CR treatment, the number, abundance, and density of zooplankton species were much higher after IR treatment. These results suggest that the coexistence of macrophytes with different life forms increases zooplankton abundance and diversity. 


\section{Table I}

Species list of zooplankton according to the level of removal of free-floating macrophytes at the study sites. NR. No Removal; IR, Intermediate Removal; CR, Complete Removal. The species with * mark were considered as epiphytic zooplankton species, in accordance with Sakuma et al. (2000) and Gyllström et al. (2005).

\begin{tabular}{|c|c|c|c|}
\hline Taxa & NR & IR & CR \\
\hline \multicolumn{4}{|l|}{ Aschelminthes } \\
\hline \multicolumn{4}{|l|}{ Eurotatorea } \\
\hline Anuraeopsis fissa (Gosse, 1851) & & + & \\
\hline Brachionus angularis (Gosse, 1851) & & + & + \\
\hline B. quadridentatus (Hermann, 1783) & & & + \\
\hline Colurella obtusa (Gosse, 1886) & & + & \\
\hline Euchlanis dilatata (Ehrenberg, 1832) & & + & \\
\hline Keratella valga (Ehrenberg, 1834) & & & + \\
\hline Lecane bulla (Gosse, 1851)* & & + & \\
\hline L. closterocerca (Schmarda, 1859)* & & + & \\
\hline L. furcata (Murray, 1913)* & & + & \\
\hline L. hamata (Stokes, 1897)* & + & + & \\
\hline L. ludwigii (Eckstein, 1893)* & + & + & \\
\hline L. pygmaea (Daday, 1897)* & & + & \\
\hline Lepadella oblonga (Harring, 1913)* & & + & \\
\hline Monommata grandis (Tessin, 1890) & + & & \\
\hline Mytilina ventralis (Ehrenberg, 1832) & + & + & \\
\hline Notholca labis (Gosse, 1887) & & & + \\
\hline Philodina roseola (Ehrenberg, 1832) & & + & \\
\hline Platyias patulus (Müller, 1786) & & + & + \\
\hline Ploesoma hudsoni (Imhof, 1891) & & & + \\
\hline P. truncatum (Levander, 1894) & & + & \\
\hline Polyarthra remata (Skorikov, 1896) & & + & + \\
\hline Squatinella mutica (Ehrenberg, 1832) & & & + \\
\hline Synchaeta stylata (Wierzejski, 1893) & & + & \\
\hline Testudinella patina (Hermann, 1783) & + & + & \\
\hline Trichocerca gracilis (Tessin, 1890)* & + & & + \\
\hline T. pusilla (Lauterborn, 1898)* & & + & \\
\hline T. rattus (Müller, 1776)* & & + & \\
\hline Trichotria pocillum (Müller, 1776)* & & + & + \\
\hline T. tetractis (Ehrenberg, 1830)* & & + & \\
\hline \multicolumn{4}{|l|}{ Arthropoda } \\
\hline \multicolumn{4}{|l|}{ Crustacea } \\
\hline Acroperus harpae (Baird, 1835)* & & + & \\
\hline Alona guttata (Sars, 1862)* & + & + & \\
\hline A. rectangula (Sars, 1862$)^{*}$ & & + & \\
\hline Bosmina longirostris (Müller, 1785) & & + & + \\
\hline Camptocercus rectirostris (Schoedler, 1862)* & & + & \\
\hline Chydorus sphaericus (Müller, 1785)* & + & + & \\
\hline Cyclops vicinus (Uljanin, 1875) & & + & + \\
\hline Daphnia obtusa (Kurz, 1874) & & + & + \\
\hline Diaphanosoma brachyurum (Liévin, 1848) & & & + \\
\hline Graptoleberis testudinaria (Fischer, 1848)* & & + & \\
\hline Ilyocryptus spinifer (Herrick, 1882)* & + & + & \\
\hline Mesocyclops leuckarti (Claus, 1857) & & + & + \\
\hline Moina macrocopa (Straus, 1820)* & & + & + \\
\hline Pleuroxus aduncus (Jurine, 1820)* & + & + & \\
\hline P. laevis (Sars, 1862)* & & + & + \\
\hline Simocephalus exspinosus (Koch, 1841)* & & + & \\
\hline S. vetulus (Müller, 1776)* & + & + & \\
\hline Scapholeberis kingi (Sars, 1903)* & & & + \\
\hline Thermocyclops crassus (Fischer, 1853) & & + & \\
\hline T. taihokuensis (Harada, 1931) & & + & + \\
\hline
\end{tabular}



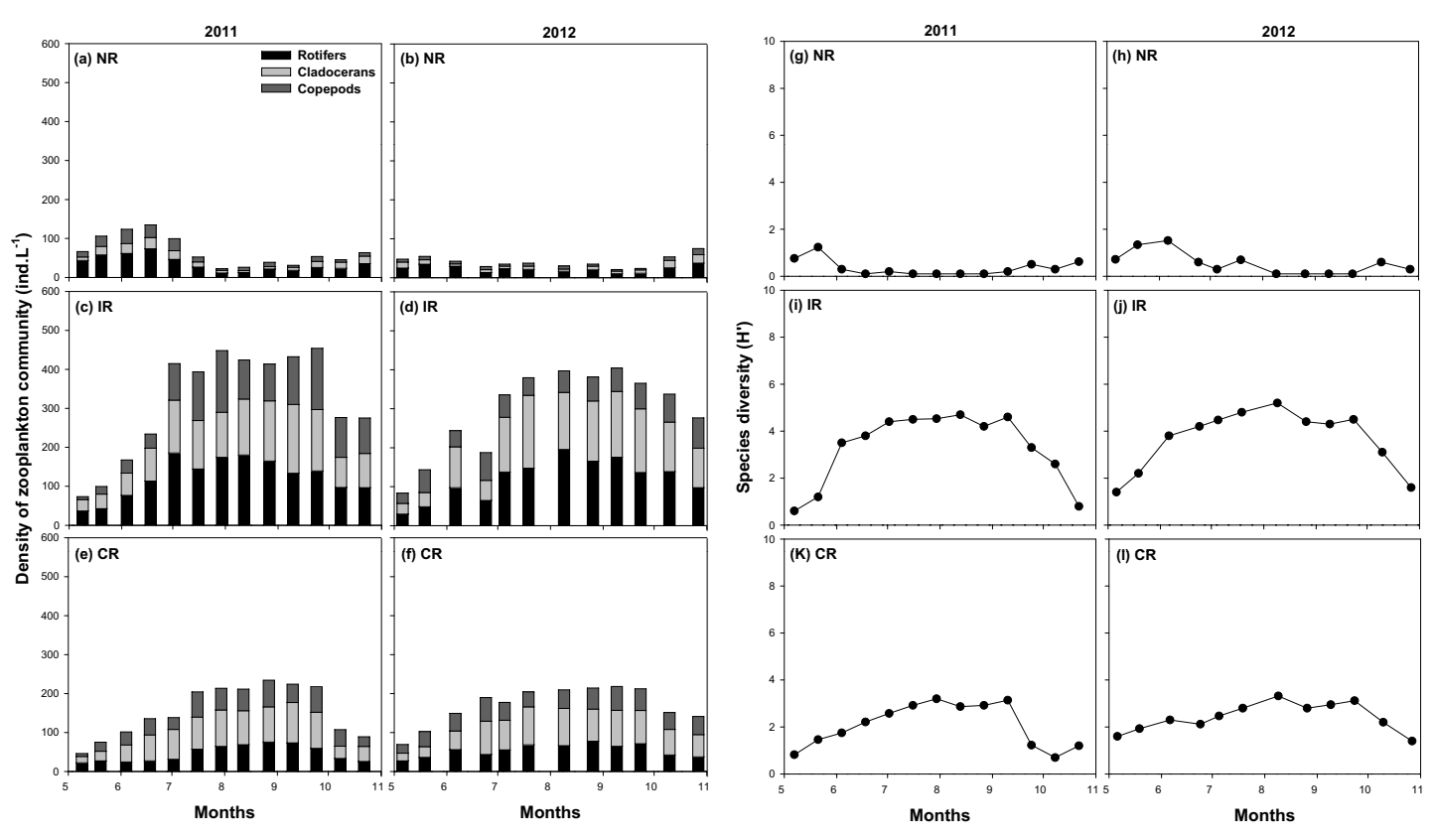

Figure 4

Seasonal density and species diversity of zooplankton communities according to the level of freefloating macrophyte removal at the study site. NR, No Removal; IR, Intermediate Removal; CR, Complete Removal.

Intense macrophyte removal altered aquatic environmental characteristics, but the pattern of change was not proportional to the increase in zooplankton diversity. Among the three treatments, CR of free-floating macrophytes allowed more light penetration and led to increased chlorophyll a concentration, which resulted in increased dissolved oxygen and $\mathrm{pH}$. Typically, increases in phytoplankton biomass (often represented as chlorophyll a concentration) cause increased zooplankton abundance because the zooplankton use phytoplankton as a food source (Choi et al., 2014a). However, in this study, enhancement of food availability did not cause a proportional increase in zooplankton. Habitat heterogeneity, rather than the aquatic physiochemical environment, affected the species diversity and abundance of zooplankton. Thus, heterogeneity of the microhabitats within the quadrats is believed to have had a stronger influence on the richness of the zooplankton community than the increase in chlorophyll a concentration.

Some studies have suggested that freshwater macrophytes not only provide fundamental microhabitats but are also utilized as a food resource and a refuge for predator avoidance (Meerhoff et al., 2006, 2007). Zooplankton (mainly rotifers and cladocerans) utilize macrophytes efficiently. Complexly structured macrophytes, such as submerged macrophytes, enhance the opportunities that zooplankton have for avoiding predators, and the surfaces of their stems and leaves are important attachment sites for epiphytic zooplankton (Stansfield et al., 1997; Muylaert et al., 2010), creating a complex habitat that makes a large contribution to zooplankton assemblages (Meerhoff et al., 2007). However, some reports have claimed that submerged macrophytes were mainly used by pelagic zooplankton, such as daphnids, as their daytime refuge (Lauridsen and Lodge, 1996; Burk et al., 2002), and that a large number of zooplankton species often inhabit floating-leaved or free-floating macrophytes. Moss et al. (1998) and Choi et al. (2014b) suggested that some epiphytic zooplankton species could attain high biomass in floating-leaved macrophyte beds. The increase in zooplankton abundance and species number after IR treatment can be explained by this dynamic. We found a total of 25 epiphytic species during the study period (see Table I) and a similar number of pelagic species. CR quadrats were mainly dominated by pelagic zooplankton and had low densities of epiphytic species. In contrast, the IR treatment led to the coexistence of pelagic 
and epiphytic zooplankton and the largest zooplankton abundance. Consequently, the diversity of macrophyte species or life forms is crucial factors in determining the structure of zooplankton assemblages.

In this study, different types of zooplankton species (i.e., pelagic and epiphytic) coexisted in the IR quadrats. Pelagic species were not found in the NR quadrats (i.e., quadrats covered by free-floating macrophytes) and epiphytic species were not present in samples from the $\mathrm{CR}$ quadrats (i.e., quadrats containing only submerged macrophytes). These findings imply that greater microhabitat complexity would promote more species diversity in wetlands. The resource demands of pelagic and epiphytic zooplankton species differ; pelagic species require space for predator avoidance and frequent movement, whereas epiphytic species need more substrates for food resource exploitation. We assumed that these different habitat requirements have led the zooplankton species to utilize plant life forms differently and that the simultaneous presence of different types of macrophytes, forming complex aquatic microhabitats, induces high zooplankton species diversity and density. Consequently, we suggest that moderate disturbance (either natural or artificial) to free-floating macrophyte development can promote higher zooplankton diversity, which may lead to a more ecologically sound food-web structure in wetlands.

\section{ACKNOWLEDGEMENTS}

This research was supported by the Basic Science Research Program through the National Research Foundation of Korea (NRF) funded by the Ministry of Education (grant number: NRF-2012-R1A6A3A04040793).

\section{REFERENCES}

Barko J.W., Hardin D.G. and Matthews M.S., 1982. Growth and morphology of submersed freshwater macrophytes in relation to light and temperature. Can. J. Botany, 60, 877-887.

Burks R.L., Lodge D.M., Jeppesen E. and Lauridsen T.L., 2002. Diel horizontal migration of zooplankton: costs and benefits of inhabiting littoral zones. Freshwater Biol., 47, 343-365.

Choi J.Y., Kim S.K., Chang K.H., Kim M.C., La G.H., Joo G.J. and Jeong K.S., 2014a. Population growth of the cladoceran, Daphnia magna: A quantitative analysis of the effects of different algal food. PLoS One 9, e95591.

Choi J.Y., Jeong K.S., La G.H., Kim S.K. and Goo G.J., 2014b. Sustainment of epiphytic microinvertebrate assemblage in relation with different aquatic plant microhabitats in freshwater wetlands (South Korea). J. Limnol., 73, 11-16.

Forchhammer N.C., 1999. Production potential of aquatic plants in systems mixing floating and submerged macrophytes. Freshwater Biol., 41, 183-191.

Gross E.M., Hilt S., Lombardo P. and Mulderij G., 2007. Searching for allelopathic effects of submerged macrophytes on phytoplankton - state of the art and open questions. Hydrobiologia, 584, 77-88.

Gyllström M., Hansson L.A., Jeppesen E., García-Criado F., Gross E., Irvine K., Kairesalo T., Kornijow R., Miracle M.R., Nykänen M., Nõges T., Romo S., Stephen D., Van Donk E. and Moss B., 2005. The role of climate in shaping zooplankton communities of shallow lakes. Limnol. Oceanogr., 50 , 2008-2021.

Jeppesen E., Jensen J.P., Søndergaard M., Lauridsen T., Pedersen L.J. and Jensen L., 1997. Top-down control in freshwater lakes: the role of nutrient state, submerged macrophytes and water depth. Hydrobiologia, 342/343, 151-164.

Lauridsen T.L. and Lodge D.M., 1996. Avoidance by Daphnia magna of fish and macrophytes: chemical cues and predator-mediated use of macrophyte habitat. Limnol. Oceanog., 41, 794-798.

Manatunge J., Aseada T. and Priyadarshana T., 2000. The influence of structural complexity on fishzooplankton interactions: A study using artificial submerged macrophytes. Environ. Biol. Fishes, 58, 425-438.

Meerhoff M., Mazzeo N., Moss B. and Rodríguez-Gallego L., 2003. The structuring role of free-floating versus submerged plants in a subtropical shallow lake. Aquat. Ecol. 37, 377-391. 
Meerhoff M., Fosalba C., Bruzzone C., Mazzeo N., Noordoven W. and Jeppesen E., 2006. An experimental study of habitat choice by Daphnia: plants signal danger more than refuge in subtropical lakes. Freshwater Biol., 51, 1320-1330.

Meerhoff M., Iglesias C., Teixeira de Mello F., Clemente J.M., Jensen E., Lauridsen T.L. and Jeppesen E., 2007. Effects of habitat complexity on community structure and predator avoidance behavior of littoral zooplankton in temperate versus subtropical shallow lakes. Freshwater Biol., 52, 1009-1021.

Mizuno T. and Takahashi E., 1999. (Eds). An illustrated guide to freshwater zooplankton in Japan. Tokai University press, Tokyo.

Moss B., Kornijow R. and Measey G., 1998. The effect of nymphaeid (Nuphar lutea) density and predation by perch (Perca fluviatilis) on the zooplankton communities in a shallow lake. Freshwater Biol., 39, 689-697.

Muylaert K., Pérez-Martínez C., Sánchez-Castillo P., Lauridsen T.L., Vanderstukken M., Declerck S.A.J., Van der Gucht K., Conde-Porcuna J.M., Jeppesen E., De Meester L. and Vyverman W., 2010. Influence of nutrients, submerged macrophytes and zooplankton grazing on phytoplankton biomass and diversity along a latitudinal gradient in Europe. Hydrobiologia, 653, 79-90.

O'Hare M.T., Baattrup-Pedersen A., Nijboer R., Szoszkiewicz K. and Ferreira T., 2006. Macrophyte communities of European streams with altered physical habitat. Hydrobiology, 566, 197-210.

Pelicice F.M. and Agostinho A.A., 2006. Feeding ecology of fishes associated with Egeria spp. patches in a tropical reservoir, Brazil. Ecol. Freshw. Fish, 15, 10-19.

Sakuma M., Hanazato T., Nakazato R. and Haga H., 2002. Methods for quantitative sampling of epiphytic microinvertebrates in lake vegetation. Limnology, 3, 115-119.

Shannon C.E. and Weaver W., 1949. A mathematical theory of communication. University of Illinois Press, Urbana, USA.

Smokorowski K.E. and Pratt T.C., 2007. Effect of a change in physical structure and cover on fish and fish habitat in freshwater ecosystems - a review and meta-analysis. Environ. Rev., 15, 15-41.

Stansfield J.H., Perrow M.R., Tench L.D., Jowitt A.J.D. and Taylor A.A.L., 1997. Submerged macrophytes as refuge for grazing Cladocera against fish predation: observations on seasonal changes in relation to macrophyte cover and predation pressure. Hydrobiologia, 342-343, 229-240.

Tolonen K.T., Holopainen I.J., Hämäläinen H., Rahkola-Sorsa M., Ylöstalo P., Mikkonen K. and Karjalainen J., 2005. Littoral species diversity and biomass: concordance among organismal groups and the effects of environmental variables. Biodivers. Conserv., 14, 961-980.

van Donk E. and van de Bund W.J., 2002. Impact of submerged macrophytes including charophytes on phyto-and zooplankton communities: allelopathy versus other mechanisms. Aquat. Bot., 72, 261-274.

Wetzel R.G. and Likens G.E., 2000. Limnological Analyses. Springer-Verlag, New York, pp. 20-70. 